\title{
Proceeding
}

Supplementary Issue: Winter Conferences of Sports Science. Costa Blanca Sports Science Events, 24 April 2020. Alicante, Spain.

\section{Experimenting with motor and sports sciences in primary school: Innovative proposals for didactics and evaluation systems}

\author{
DAVIDE DI PALMA ${ }^{1} \square$, ANTONIO ASCIONE ${ }^{2}$ \\ 1 University of Naples "Parthenope", Italy \\ 2University of Bari "Aldo Moro", Italy
}

\begin{abstract}
The Italian primary school, among its institutional teachings, requires the presence of motor and sports education, and a teacher that is specialized and competent in this discipline. Starting from this hypothesis, this research work sets itself the objective of identifying both an innovative and effective didactic-pedagogical program for the school context, and an appropriate evaluation approach consistent with the motor, sociorelational and educational objectives pursued through motor and sports sciences. Through the experimental program "Sport in Classe", the research was carried out directly in the primary school context and allowed to meet the set objectives and highlight the importance that the graduate in motor sciences could assume in the Italian primary school.

Keywords: Experimental pedagogy; Motor and sport education; Primary school; Innovative didactics; Innovative evaluation.

Cite this article as:

Di Palma, D., \& Ascione, A. (2020). Experimenting with motor and sports sciences in primary school: Innovative proposals for didactics and evaluation systems. Journal of Human Sport and Exercise, 15(2proc), S162-S172. doi:https://doi.org/10.14198/jhse.2020.15.Proc2.06
\end{abstract}

Corresponding author. University of Naples "Parthenope", Italy.

E-mail: davide.dipalma@uniparthenope.it

Supplementary Issue: Winter Conferences of Sports Science. Costa Blanca Sports Science Events, 24 April 2020. Alicante, Spain.

JOURNAL OF HUMAN SPORT \& EXERCISE ISSN 1988-5202

(c) Faculty of Education. University of Alicante

doi:10.14198/jhse.2020.15.Proc2.06 


\section{INTRODUCTION}

The impact with the educational contexts, particularly with their methodological and evaluation aspects, represents one of the most significant experiences in the individual's education.

This research work aims at reflecting on the docimological aspects and the relationship with the didactic methodology of the new school system, specifically in the field of motor and sports sciences. The two main strands consider the following concepts (Ascione, Di Palma \& Rosa, 2019; Bartezzaghi, Guerci \& Vinante, 2010; Di Palma, lovino \& Ascione, 2019; Giannandrea, 2010; lavarone \& Lo Presti, 2015):

- Evaluation: a tool to test the achievement of an objective and the method used, both in relation to the individual and the community and in relation to the teachers themselves, in order to have a feedback on their work. It does not take place at the end of a process, but rather supports it in its development. It controls the adequacy of the tools, assuming a scientific attitude of research, sense and meaning. "We do not evaluate to evaluate, but to educate, to change for the better, where and when necessary."

- Innovative didactics: a way through which students' skills and knowledge are enhanced thanks to new learning methodologies, from E-learning to team working, through experiences of exchange and sharing that increase the student's involvement and bring the class to a much higher level of communication. In a perspective of innovative didactics, the student has the opportunity to achieve a plurality of objectives of relevant importance: acquiring cultural and knowledge-based tools to face the world; developing methods and skills that allow him/her gain autonomy and critical skills; being able to identify tools that allow him/her approaching reality with a critical, open, responsible and competent spirit.

By using new didactic and evaluative methods during the implementation of the Italian Ministerial Project "Sport di Classe", the pedagogical approach behind this experience turned out to be "experimental", and attention was paid to the figure of the graduate in motor science, enhancing the skills and responsibilities that this figure could, and should, cover in the school environment.

\section{THE STRUCTURE OF THE PROJECT}

The reflection on the two previously highlighted topics took place during the implementation of the "Sport di Classe" Project carried out in the academic year 2018/2019 in an Italian primary school, led by graduates in Motor Sciences through the scientific supervision of experts in Didactics, Experimental Pedagogy and Motor Education. "Sport di Classe" is a project managed and funded by the CONI (Italian National Olympic Committee), in order to promote motor education and the values of sport within school contexts, aimed at students attending 4th and 5th grade classes. The project lasted 6 months and took 2 hours per class, 1 of which was in the presence of the external sports tutor.

\section{Aim of the project}

The aim of the working group was to focus attention on innovative didactic methods and new evaluation systems proposed to students by the external tutor. The proposed methodologies were then compared with those of the teaching staff, underlining the differences between the two and highlighting the critical issues on both sides, giving particular importance to the different feedback from the individual and from the class group. 


\section{Basic aspects of the project}

The first meeting with the classes took place in December 2018. Initially, an overview of the classes was presented to the tutors: the teachers of the school presented the classes to be monitored during the project, showing the general progress of the group and of the individuals, and pointing out difficulties in carrying out the lessons, where present. The first cognitive phase was fundamental, since it allowed understanding the method used by the teaching staff of the school and the relationship created between teacher and learners. In some cases it was possible to ascertain that the methodology used was a mix between traditional models and approaches that were closer to the so-called innovative didactics: the use of multimedia blackboards and of team working activities was monitored through the use of paper tools, dictation of assignments, frontal lessons, a teacher-student relationship that was not always in line with the innovative models, but the result of a personal cultural background of the teacher, who privileged a distant relationship with the students and where the evaluation criteria were strongly influenced by subjective factors.

At the end of the first cognitive phase in the school context, the teachers submitted the evaluation grids in use to the tutors, which included the Italian ministerial parameters/criteria of reference.

Table 1. Traditional evaluation grids employed in motor and sport sciences.

\begin{tabular}{|c|c|c|c|c|}
\hline \multirow{8}{*}{$\begin{array}{l}\text { Core Themes } \\
\text { The body and its } \\
\text { relationship with } \\
\text { time and space. }\end{array}$} & Skills & Learning Objectives & Descriptors & Mark \\
\hline & \multirow{7}{*}{$\begin{array}{l}\text { The student acquires self- } \\
\text { awareness by perceiving } \\
\text { his/her own body, and } \\
\text { mastering motor and } \\
\text { postural patterns in } \\
\text { continuous adaptation to } \\
\text { spatial and temporal } \\
\text { variables. }\end{array}$} & \multirow{2}{*}{$\begin{array}{l}\text { Coordinating within a } \\
\text { space in relation to things } \\
\text { and people. }\end{array}$} & $\begin{array}{l}\text { He/she coordinates within } \\
\text { a space: }\end{array}$ & \\
\hline & & & Safely & 10 \\
\hline & & \multirow{5}{*}{$\begin{array}{l}\text { Knowing and applying } \\
\text { correctly how to play } \\
\text { movement games. }\end{array}$} & Completely & 9 \\
\hline & & & Correctly and accurately & 8 \\
\hline & & & Correctly & 7 \\
\hline & & & Fairly correctly & 6 \\
\hline & & & Inadequately & 5 \\
\hline \multirow{7}{*}{$\begin{array}{l}\text { Body language as } \\
\text { a communicative- } \\
\text { expressive } \\
\text { modality. }\end{array}$} & \multirow{7}{*}{$\begin{array}{l}\text { The student uses motor } \\
\text { and body language to } \\
\text { express his/her moods, } \\
\text { also through } \\
\text { dramatizations and } \\
\text { rhythmic-musical and } \\
\text { choreutical experiences. }\end{array}$} & \multirow{7}{*}{$\begin{array}{l}\text { Planning increasingly } \\
\text { complex motor actions by } \\
\text { coordinating various } \\
\text { movement patterns. }\end{array}$} & $\begin{array}{l}\text { He/she plans complex } \\
\text { motor actions: }\end{array}$ & \\
\hline & & & Safely & 10 \\
\hline & & & Completely & 9 \\
\hline & & & Correctly and accurately & 8 \\
\hline & & & Correctly & 7 \\
\hline & & & Fairly correctly & 6 \\
\hline & & & Inadequately & 5 \\
\hline \multirow{7}{*}{$\begin{array}{l}\text { Game, sport, rules } \\
\text { and fair play. }\end{array}$} & \multirow{7}{*}{$\begin{array}{l}\text { The student lives a } \\
\text { plurality of experiences } \\
\text { and technical gestures that } \\
\text { allow him/her to develop } \\
\text { game-sports skills also as } \\
\text { orientation to future sports } \\
\text { practice. } \\
\text { He/she understand the } \\
\text { value of the rules thanks to } \\
\text { the various game and } \\
\text { sports occasions. }\end{array}$} & \multirow{7}{*}{$\begin{array}{l}\text { Learning, applying and } \\
\text { respecting the rules in the } \\
\text { various game forms. }\end{array}$} & $\begin{array}{l}\text { He/she applies the basic } \\
\text { rules in the game } \\
\text { dynamics: }\end{array}$ & \\
\hline & & & $\begin{array}{l}\text { Always correctly, with } \\
\text { self-control and by } \\
\text { cooperating with others }\end{array}$ & 10 \\
\hline & & & $\begin{array}{l}\text { Correctly, with self- } \\
\text { control }\end{array}$ & 9 \\
\hline & & & Accurately & 8 \\
\hline & & & Correctly & 7 \\
\hline & & & $\begin{array}{l}\text { Poorly accurately and } \\
\text { difficultly }\end{array}$ & 6 \\
\hline & & & Inadequately & 5 \\
\hline
\end{tabular}




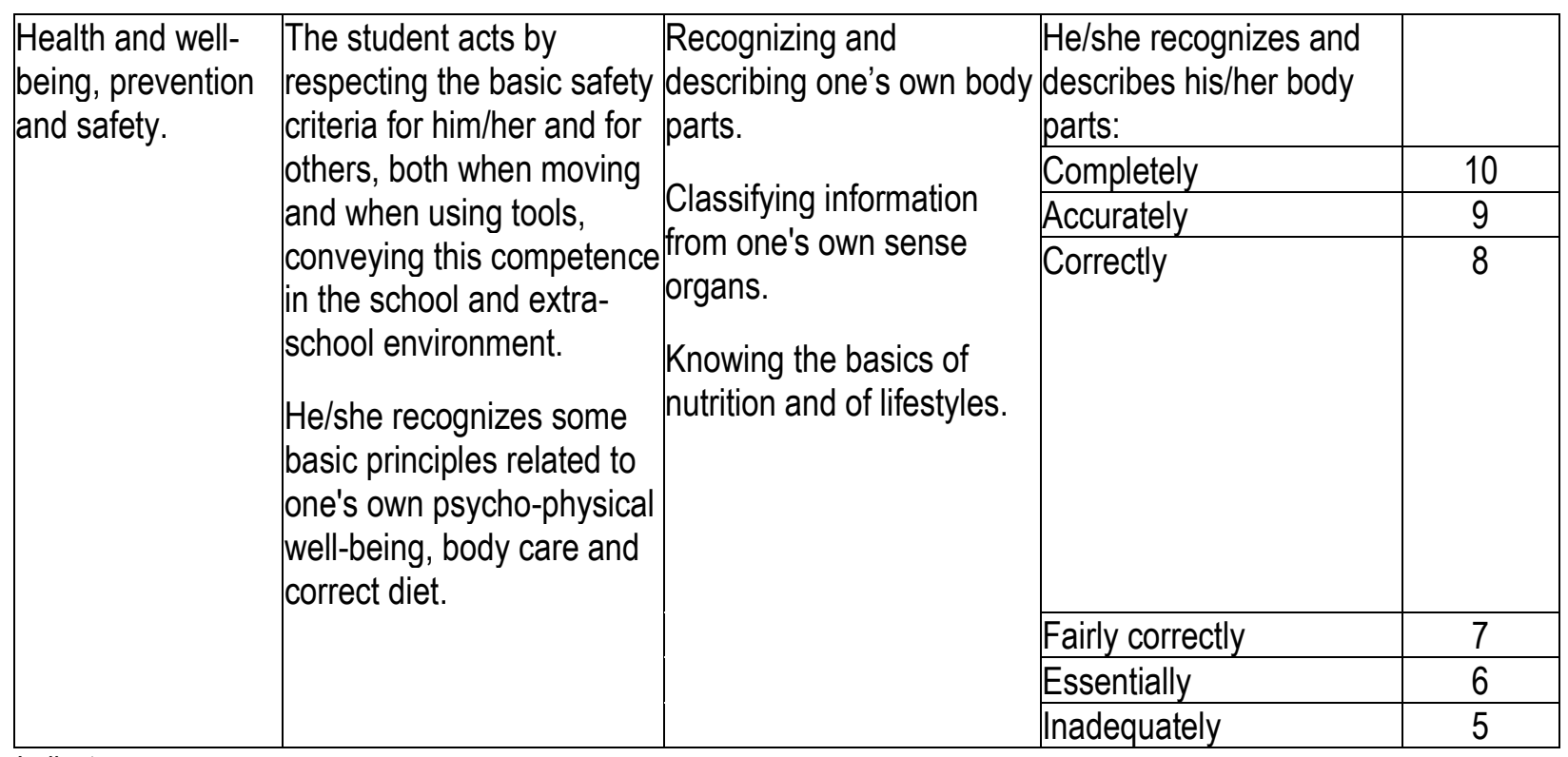

Indicators:

- The body and its relationship with space and time

- Body language as a communicative-expressive modality

- Game, sport, rules and fair play.

- Health and well-being, prevention and safety.

\section{Implementation phase of the experimental project}

When implementing the project, attempts were made to use new teaching and evaluation methods that could best represent innovative didactics. Initially, great importance was given to the relationship with the students. The subjects were given the opportunity to actively participate in the lessons and to feel part of the class group, where everyone had the opportunity to express their ideas, to compare them with others, and to decide together the best decisions. During the first lesson we wanted to send a strong communicative message to the class: the tutor was placed in circle together with the students sitting on chairs at the same height; there was a presentation phase followed by a second one where, thanks to the contribution of all those present and by common agreement, a few simple rules to be followed during the school year, both by the students and by the tutor, were outlined.

The lessons were inspired by various models of innovative didactics (Di Palma \& Ascione, 2020; lavarone, 2013; Sibillio \& Aiello, 2011):

- They were held in the gym but moved to open and natural places within the institute whenever possible (Outdoor Training model), with the aim of involving the students more in a different environment than the ones in which they were usually used to confront each other and the teachers.

- Some game-activities proposed by the tutor set goals to be achieved by limiting the tools available to the class. This type of activity gave the individual and the group the possibility to reach the specific goal of the game through a simplexity, cooperation and collaboration process, inspired by the problem-solving and Brain Storming models.

- Team games, inspired by the Business Game model, increased competitiveness by giving students the opportunity to convey more insights on the values of sport, on the importance of oneself and the other. 


\section{THE PROPOSAL FOR INNOVATIVE DIDACTICS THROUGH COOPERATION}

The influence of the innovative didactics models and the positive feedback received made it possible for the tutors to experiment with their idea in a context they considered suitable.

It was proposed to divide the class into heterogeneous groups (by gender, city of origin and position within the class), keep the group for a week (until the subsequent lesson) and then make a different division from the previous one.

The groups were assigned 3 tools that changed in the subsequent weeks.

The task of the group was to present a game proposal in which each member of the team had introduced an element (tool, rule, space limit, time limit) characterizing the activity.

The aim of the work was to evaluate not so much the ability of each individual to perform a specific motor task, but to elaborate "outside-the-box" proposals by discussing with the group, to develop a sense of cooperation, creativity, belonging to the group and the ability to integrate the other, to understand the symbolic message of sport, to listen and accept one's own and the other's mistakes.

In particular, with this type of activity, the student and the group actively participated in the classroom context, developing communicative skills and laying the foundations for innovative didactics, within which the subject could feel gratified and accepted by the peer group, in a non-judgmental but constructive perspective.

In the weeks following the presentation of the games realized by the students, a clear improvement in the class atmosphere was observed, with an increase in the subjects' cooperation also in extra sports activities, and improved degree of integration for those subjects who, until that moment, still played a passive role in the class community.

A decreased degree of negative judgment within the peer group, and a peak in the degree of attention and efficiency of the students, was satisfactorily observed.

In this renewed positive climate, the communicative and relational skills between teacher and learner considerably improved, with a positive impact in every school sphere.

\section{DEVELOPING INNOVATIVE EVALUATION GRIDS FOR MOTOR AND SPORTS EDUCATION}

Since school evaluation is one of the aspects that students feel most strongly about, it is often seen - both in a positive and negative sense - as a key to interpreting personal educational history and has great influence on the choices and behaviour adopted by each individual (Damiani, 1993; De Landsheere, 1994). The evaluation system established at school and the way in which it is applied proposes values or disvalues that are gradually internalized both by the subject and by the local community. For example, the marks that children get at school can affect their sense of self-esteem, i.e. the more or less positive image that they build about themselves, especially when these messages come from people who are meaningful to them, such as the teachers. Moreover, the evaluation also seems to affect the sense of self-efficacy, i.e. the perception of being able to engage in studying in order to improve, regardless of the grade itself. 
Therefore, evaluation (in general) should not be understood and managed by teachers as an external control over the learning process, but as additional information supporting the students, who are personally responsible for how and how much they learn and for their own growth (Bartezzaghi, Guerci \& Vinante, 2010; Gentili, 2016; Giannandrea, 2010; Maccario, 2012). When preparing the evaluation grids, it is important to consider the evaluation-learning process as something that evaluates the learner's path and their approach to it.

In the "Sport di Classe" Project a different approach was also adopted with regard to the evaluation system. Unlike the initial evaluation grid, in agreement with the teaching staff, a different one was used; the latter, while following the Italian ministerial guidelines, is structured in a more students-centred way and is more related to the process of methodological innovation that was implemented in the classes.

In the evaluation grid used by the sports tutors, new reference criteria concerning the didactic methods used were included, which support the aspects that strongly impacted the project. The active role during the lessons and the students' behaviour are two fundamental elements in a perspective of continuous evaluation, which have to be taken into consideration in a process of educational and formative growth for the subject (Bruner, 2001; Kanizsa, S., \& Tramma, 2011).

Table 2. Innovative evaluation grids in motor and sport sciences.

\begin{tabular}{|c|c|c|c|c|}
\hline Core Themes & Skills & Learning Objectives & Descriptors & Mark \\
\hline \multirow[t]{7}{*}{ Movement } & \multirow{7}{*}{$\begin{array}{l}\text {-Conditional, } \\
\text { coordination and } \\
\text { motor skills. }\end{array}$} & \multirow{7}{*}{$\begin{array}{l}\text {-Mastery of complex } \\
\text { motor actions in } \\
\text { variable situations } \\
\text { with personal } \\
\text { solutions. } \\
\text { - Using and } \\
\text { controlling motor } \\
\text { actions. }\end{array}$} & Total and complete & 10 \\
\hline & & & Complete & 9 \\
\hline & & & Excellent & 8 \\
\hline & & & Good & 7 \\
\hline & & & Sufficient & 6 \\
\hline & & & Insufficient & 5 \\
\hline & & & Poor & 4 \\
\hline \multirow{9}{*}{$\begin{array}{l}\text { Body language as a } \\
\text { communicative- } \\
\text { expressive modality }\end{array}$} & \multirow{9}{*}{$\begin{array}{l}\text {-Using motor and } \\
\text { body language to } \\
\text { express ideas and } \\
\text { moods, and to relate } \\
\text { to others. }\end{array}$} & \multirow{9}{*}{$\begin{array}{l}\text {-Using multiple } \\
\text { specific, } \\
\text { communicative and } \\
\text { expressive languages } \\
\text { transmitting emotional } \\
\text { content. } \\
\text {-Ability to use the } \\
\text { body to express } \\
\text { verbal, non-verbal } \\
\text { and para-verbal } \\
\text { messages. }\end{array}$} & & \\
\hline & & & Total and complete & 10 \\
\hline & & & Complete & 9 \\
\hline & & & Correct and accurate & 8 \\
\hline & & & Correct & 7 \\
\hline & & & Fairly correct & 6 \\
\hline & & & Inappropriate & 5 \\
\hline & & & Severely inappropriate & 4 \\
\hline & & & & \\
\hline \multirow{7}{*}{$\begin{array}{l}\text { Game-sports and } \\
\text { fair play }\end{array}$} & \multirow{7}{*}{$\begin{array}{l}\text {-Understanding the } \\
\text { values-focused } \\
\text { message of sport. } \\
\text {-Accepting one's own } \\
\text { mistakes and those of } \\
\text { others. }\end{array}$} & \multirow{7}{*}{$\begin{array}{l}\text {-Understanding the } \\
\text { importance of the } \\
\text { group. } \\
\text {-Integrating the other. } \\
\text {-Ability to cooperate } \\
\text { and respect the rules. }\end{array}$} & Always correct & 10 \\
\hline & & & Correct & 9 \\
\hline & & & Good self-control & 8 \\
\hline & & & Fair self-control & 7 \\
\hline & & & Sufficient & 6 \\
\hline & & & Insufficient & 5 \\
\hline & & & Poor & 4 \\
\hline
\end{tabular}




\begin{tabular}{|c|c|c|c|c|}
\hline \multirow{7}{*}{$\begin{array}{l}\text { Active role during } \\
\text { lessons }\end{array}$} & \multirow{7}{*}{$\begin{array}{l}\text {-Proposing and taking } \\
\text { part in school } \\
\text { activities. }\end{array}$} & \multirow{7}{*}{$\begin{array}{l}\text {-Developing the ability } \\
\text { to promote activities } \\
\text { for oneself and for the } \\
\text { class group. } \\
\text {-Engaging actively in } \\
\text { each other's } \\
\text { proposals. }\end{array}$} & Active participation & 10 \\
\hline & & & Constant participation & 9 \\
\hline & & & Inconstant participation & 8 \\
\hline & & & Poor participation & 7 \\
\hline & & & Poorly active & 6 \\
\hline & & & Non-participatory & 5 \\
\hline & & & Inactive & 4 \\
\hline \multirow[t]{7}{*}{ Behaviour } & \multirow{7}{*}{$\begin{array}{l}\text {-Improving the } \\
\text { relationship with the } \\
\text { class group. } \\
\text {-Encouraging the } \\
\text { process of inclusion } \\
\text { of the other. } \\
\text {-Respecting the rules } \\
\text { agreed upon together. }\end{array}$} & \multirow{7}{*}{$\begin{array}{l}\text {-Understanding the } \\
\text { values of cooperation, } \\
\text { collaboration and } \\
\text { mutual respect. } \\
\text {-Developing a sense } \\
\text { of respect for the } \\
\text { rules and for the } \\
\text { other. }\end{array}$} & Excellent & 10 \\
\hline & & & Almost excellent & 9 \\
\hline & & & Very good & 8 \\
\hline & & & Good & 7 \\
\hline & & & Sufficient & 6 \\
\hline & & & Insufficient & 5 \\
\hline & & & Poor & 4 \\
\hline
\end{tabular}

\section{QUALITATIVE EVALUATION OF THE PROJECT}

At the end of the project a questionnaire was administered by the institute to the teaching staff, in order to evaluate the quality of the didactics proposed by the tutor, the coordination, collaboration and integration skills between the two professional figures and the feedback of the classes and of the individuals.

\section{Evaluation questionnaire for tutors "Sport di Classe" project comprehensive institute 'Bozzaotra'}

1) Were the resources deployed for the project activities available and effective?

o Not much

- Enough

○ Very much

2) Was the didactic methodology used by the expert more suitable for learning?

o Not much

- Enough

- Very much

3) Did the expert play a role in the didactics?

o Not much

- Enough

- Very much

4) Did the students show interest in the activities carried out?

o Not much

- Enough

○ Very much

5) Were the students involved in various group activities?

o Not much

- Enough

○ Very much 
6) Do you think that the educational action of the project could have an impact on the educationaldidactic process of the school?

- Not much

- Enough

$\circ \quad$ Very much

7) Did the calendar of meetings (hours and days) seem appropriate and functional to the planned activities?

- Not much

- Enough

$\circ \quad$ Very much

8) Was the atmosphere in which the activities took place relaxed and collaborative?

- Not much

- Enough

- Very much

9) Did you feel involved in the implementation of the project?

- Not much

- Enough

- Very much

10) Did you have the opportunity to discuss with the expert?

- Not much

- Enough

- Very much

11) Did the expert ask for your opinion on the carrying out of the activities?

- Not much

$\circ \quad$ Enough

- Very much

12) Were the resources made available for the project to the school (materials, space) sufficient?

- Not much

- Enough

- Very much

13) Was the expert teacher able to interact properly with the tutor?

- Not much

- Enough

- Very much

14) Was the communication with the students effective?

- Not much

- Enough

- Very much 
15) Was the expert able to manage his/her relationships with the students?

- Not much

- Enough

○ Very much

16) Did the expert appear to be available for any issues that arose?

- Not much

- Enough

$\circ \quad$ Very much

17) Do you think it would be useful to re-propose a module with this activity for future students?

- Not much

- Enough

- Very much

18) If possible, how much do you consider it necessary to reconfirm the expert?

- Not much

- Enough

$\circ \quad$ Very much

\section{Results of the questionnaire}

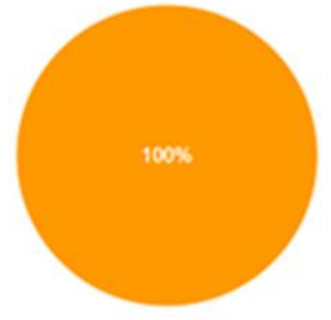

ANSWERS TO QUESTIONS $N^{\circ} 2 / 3 / 4 / 5 / 9 / 10 / 11 / 13 / 14 / 15 / 16 / 17 / 18$

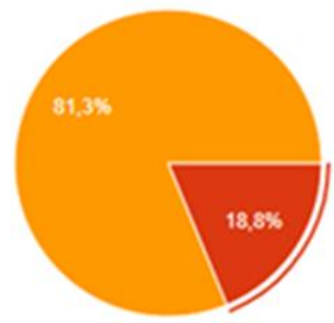

ANSWERS TO QUESTIONS N.6/8

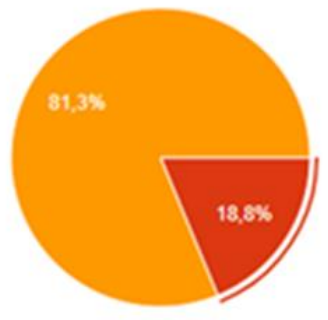

ANSWERS TO QUESTION N.1

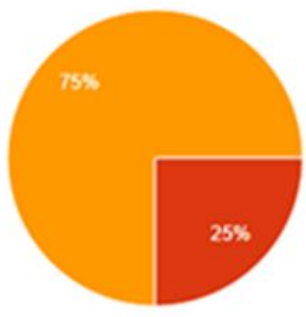

ANSWERS TO QUESTION N.7

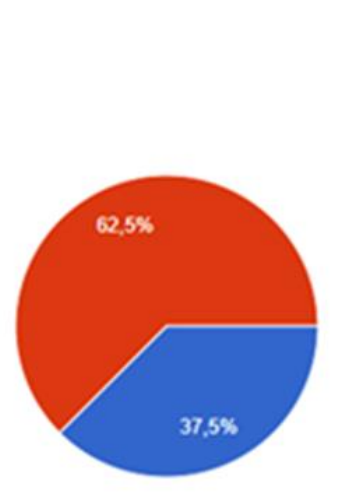

- Not much

- Enough

- Very much

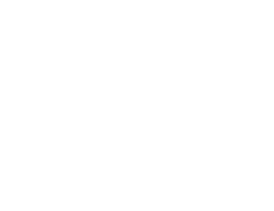

ANSWERS TO QUESTION N.12

Figure 1. Results of the questionnaire. 
By analysing the results it is possible to highlight that the critical issues that emerged within the project are not related to the work of the tutor or of the expert, but to elements that cannot be ascribed to the latter, such as the timing of the project dictated by the CONI (Italian National Olympic Committee), the inadequacy of the school facilities and the tools made available to the project.

On the other hand, the data to be underlined are those concerning the professional figure of the expert and the way the teaching staff managed to integrate the latter in the school context in the best possible way.

It is clear how the results obtained are the result of a simultaneous, parallel and coordinated work between the two figures, and that the new stimuli and ideas provided by the expert were efficiently and effectively valid for the improvement of the school's overall performance.

\section{CONCLUSIONS}

This experience made it possible to experiment with new didactic proposals that proved to be extremely effective. In addition to the aspects already dealt with previously, based on the figure of the students and their ability to live the new activities proposed, it is of fundamental importance to emphasize the ability to understand, the openness shown, the collaboration and support of the institute and especially of the teaching staff, essential to better finalize the sports/educational project. Through a constructive confrontation, a parallel planning and a tendency to accept the proposals of the other, the tutors themselves had the opportunity to live a strong moment of professional and individual growth that involved the integration of their own formative figure with that of the other teachers. In this regard, a reflection should be made on the importance of working groups aimed at training children, and on the way in which the work carried out with a plurality of professional figures, including those with specific motor and sports skills (aimed at a common goal and open to constructive confrontation), is fundamental to the improvement of the school world and to the achievement of excellent didactic and educational results.

In conclusion, we believe that it is fundamental to underline the figure of the graduate in motor science in the primary school context, being a teacher able to provide a fundamental didactic and pedagogical contribution for the educational growth of young students.

From the results obtained it is possible to deduce how the real innovation for the Italian primary education system lies exactly in the inclusion of this professional figure in the school context, and in the influence he/she has on the various educational and pedagogical aspects previously dealt with. This teacher becomes relevant to ensure the development of both aspects related to the body and the educational values of motor and sports sciences, the technical and specific contents of which fall exclusively within the competence of the graduate in motor science.

\section{AUTHOR CONTRIBUTIONS}

This research article is the result of the collective work of the 2 authors and can be specifically divided as follows:

- Antonio Ascione: Introduction - The Proposal for Innovative Didactics through Cooperation Conclusions.

- Davide Di Palma: The structure of the Project - Developing Innovative Evaluation Grids for Motor and Sports Education - Qualitative Evaluation of the Project. 


\section{REFERENCES}

Ascione, A., Di Palma, D., \& Rosa, R. (2019). Innovative educational methodologies and corporeity factor. Journal of Human Sport and Exercise, 14(2proc), S159-S168. https://doi.org/10.14198/ihse.2019.14.proc2.02

Bartezzaghi, E., Guerci, M., \& Vinante, M. (2010). La valutazione stakeholder-based della formazione continua. Milano: Franco Angeli Editor.

Bruner, J. (2001). La cultura dell'educazione (L. Cornalba Trans.).

Damiano, E. (1993). L'azione didattica: per una teoria dell'insegnamento. Armando Editor.

De Landsheere, G. (1994). Storia della pedagogia sperimentale. Cento anni di ricerca educativa nel mondo. Armando Editor.

Di Palma, D., Ascione, A. (2020). Training in school through motor education: an experimental pedagogical protocol. Sport Science, vol. 13 (2020) 1, p. 76-85.

Di Palma, D., lovino, S., \& Ascione, A. (2019). The importance of sports education in the primary school: An experimental pedagogical project. Journal of Human Sport and Exercise, 14(5proc), S1908S1924. https://doi.org/10.14198/hhse.2019.14.proc5.10

Gentili, G. (2016). Prove di competenza, compiti di realtà e rubriche di valutazione. Erickson Editor.

Giannandrea, L. (2010). Valutazione come formazione. Percorsi e riflessioni sulla valutazione scolastica. lavarone M. L. (2013). Abitare la corporeità, FrancoAngeli Editor.

lavarone, M. L., \& Lo Presti, F. (2015). Apprendere la didattica. Pensa multimedia Editor.

Kanizsa, S., \& Tramma, S. (2011). Introduzione alla pedagogia e al lavoro educativo. Carocci Editor.

Maccario, D. (2012). Valutare per promuovere il successo scolastico. Education Sciences \& Society, 2(2).

Sibilio, M., \& Aiello, P. (2011). The complexity of the educational research in the teaching of motor activities. Problems of Education in the 21st Century, 36. 